\title{
Fairness Perceptions and Experiences of Muslim University Students in Canada
}

\author{
Serdar Erkan ${ }^{1} \&$ Keith D. Walker ${ }^{2}$ \\ ${ }^{1}$ Department of Educational Sciences, Eastern Mediterranean University Famagusta, Turkish Republic of \\ Northern Cyprus \\ ${ }^{2}$ Department of Educational Administration, University of Saskatchewan Saskatoon, Canada \\ Correspondence: Serdar Erkan, Eastern Mediterranean University, College of Education Famagusta, North \\ Cyprus, Mersin 10 Turkey, Turkish Republic of Northern Cyprus. Tel: 90-392-630-4037 E-mail: \\ serdar.erkan@emu.edu.tr
}

Received: December 18, 2015 Accepted: January 23, 2016 Online Published: June 28, 2016

doi:10.5539/ies.v9n7p72 URL: http://dx.doi.org/10.5539/ies.v9n7p72

\begin{abstract}
The purpose of this article is to examine the perceptions and experiences of fairness amongst Muslim post-secondary students based on our gathering of data using a web-based survey. The participants, 189 Muslim students, were reached via student organizations, national and local Muslim organizations, and Muslim student groups organized on Facebook. Following these initial contact points, snowball sampling was used to invite prospective participants to respond to the quantitative items in the survey instrument (which also included qualitative inquiries). These quantitative responses were analyzed using descriptive statistical analysis techniques. For Muslim students, their university was perceived as the most fair amongst their experience of settings, followed by Canada in general, and the country that these Muslim students culturally most identified with. The World, at large, was perceived as the most unfair setting for responding Muslims. Except for the country that Muslim students culturally identified with, all settings were perceived to be fairer for non-Muslims than for Muslims. The majority of Muslim students reported that they had encountered, observed, or experienced unfairness at least once in their university settings during the previous academic year and that they had been impacted by that experience of unfairness.
\end{abstract}

Keywords: Muslim students, campus fairness, fairness perception, fairness experiences, international students

\section{Introduction}

For three decades internationalization has increased in institutions of higher education. Various political, economic, cultural, social, and academic rationales have created strong demands on institutions of higher education for internationalization and corresponding efforts have become important agenda items for many university administrators. Regardless of their primary rationale, nowadays the importance of internationalization is a standard priority in educational institutions all over the world. According to the results of 4th International Association of Universities Global Survey (Egron-Polak \& Hudson, 2014), 69 \% of higher education institutions, around the world, ranked internationalization as a high priority. In Canada, the Association of Universities and Colleges of Canada's (2006) findings showed that $95 \%$ of universities in Canada included an international dimension in their strategic planning processes. Examples of these dimensions included internationalization of the curriculum and student experience, as well as strategic plans for international recruitment, international partnerships and strategic alliances, exchanges (staff and students), research partnerships and alumni relations (Raftery, 2007, cited in Becket \& Brookes, 2008). Governments and international organizations have also become involved in internationalization because of economic and political interests afforded by internationalization in higher education. Strategic leadership, fiscal allocations, nationally or supra-nationally coordinated programs are some expectancies from governments or international organizations.

One well-accepted definition of the internationalization of higher education is "the process of integrating an international, intercultural, and global dimension into the purpose, functions (teaching, research, and service), and delivery of higher education at the institutional and national levels" (Knight, 2008, p. XI). There are a number of models which explain internationalization processes in higher education institutes (i.e., De Witt, 2002; Hoffmann \& Jiang, 2002, cited in Jiang, 2008; Knight, 1994). The common element articulated in these varied models was the requirement of a supportive organizational culture to host increased internationalization. 
According to Green and Olson (2003), internationalization is not merely a set of activities, but a new mindset, a culture change, and a significant curricular reform. Indeed, internationalization should encompass "distinct commitment, attitudes, global awareness, an orientation, a dimension which transcends the entire institution and shapes its ethos" (Harari, 1989, p. 2). In the kind of culture which values and supports internationalization, international students are seen as sources for enriching academic environments rather than as challenges or problems to be overcome. The diversity of student cultures is cherished, exchanged and used as a pedagogic resource (Stier, 2002). Given these perspectives, the question is: Have universities created this kind of supportive culture? If we review studies that reflect the state of internationalization, there have been some doubt about whether or not universities have been successful in creating these, aforementioned supportive cultures. According to the results of Green's (2005) study, students reported the percentage of faculty who always/frequently were observed to behave in aligned ways:

a) encouraged students to participate in international activities, equalled $15 \%$;

b) brought international reading material into their classrooms, equalled $13 \%$;

c) who discussed their international experiences in class, equalled $15 \%$;

d) related course material to larger global issues and events when possible, equalled 24\%; and

e) assigned extra credit or require students to attend internationally focused campus events equalled four percent. (pp. 20-21)

Only four percent of students reported that international students and scholars frequently or always gave presentations about their home countries (p. 21). From the same study, we can see that the percentages of students who participated in language partner program, that paired U.S. with international students, was three percent; and study groups with international students was $14 \%$, buddy program, that paired U.S. with international students, was five percent (p. 15)

In Trice's study (2007) faculty members believed that national and international students were poorly integrated and that they rarely interacted with each other. One of the reasons identified was the limited time available for social relationships. Relationships with professors were also problematic. Pilote and Benabdeljalil (2007) pointed to this problem when they explained: "Many [students] have difficulty asking questions in class or consulting the professor for fear of appearing stupid. Some [students] reported having been disappointed in the 'efficient way' in which they were treated by their professors" (para. 28). As a result of international students' unwillingness to receive counselling services (Huyn, Quinn, Madon, \& Lustig, 2007; Lu, Dear, Johnston, Wootton, \& Titov, 2014; Mori, 2000; Nilsson, Berkel, Flores, \& Lucas, 2004; Yakushko, Davidson, \& Sanford-Martens, 2008) and some universities' indifference to the challenges of international students, especially to adjustment problems (Wilson, 2011), international students become "one of the most quiet, invisible, underserved groups on the American campus" (Mori, 2000, p. 143). Knight (2011) provided similar observations that international students often undergo ethnic or racial tensions and that these students are marginalized, both socially and academically. In addition, "domestic undergraduate students are known to resist, or at best to be neutral about undertaking joint academic projects or engaging socially with foreign students - unless specific programs are developed by the university or instructor"(p. 14).

International students from different cultural backgrounds experience academic, cultural, social, psychological, and language problems (i.e., Mokua, 2012; Poyrazli \& Grahame, 2007; Poyrazli, 2015; Tung, 2012; Yeh \& Inose, 2003). Likewise, international students in Canadian universities have been found to experience several problems, including: language problems (i.e., Berman \& Cheng, 2001; Chataway \& Berry, 1989; Cheng, Myles \& Curtis, 2004; Leary, 2001; Li, 2001; Liang, 2004; Prairie Research Associates, 2009; Zhang, 2011; Zhou, 2012), academic problems (Abukhattala, 2004; Chataway \& Berry, 1989; Cheng, Myles, \& Curtis, 2004; Prairie Research Associates, 2009; Pilote \& Benabdeljalil, 2007; Leary, 201; Li, 2001; Liang, 2004; Westwood \& Barker, 1990; Zhang, 2011; Zhou, 2012), financial problems (Prairie Research Associates, 2009; Liang, 2004; Zhang, 2011; Zhou, 2012), cultural problems (Abukhattala, 2004; Chataway \& Berry, 1989; Leary, 2011; Liang; 2004; Zhang, 2011, Zhou, 2011), loneliness, isolation, lack of communication (Leary, 2011; Zhang, 2011), lack of social support (Grayson, 2008), and homesickness, anxiety, prejudice, and health problems (Leary, 2011; Chataway \& Berry, 1989).

Worse than these problems are the reports of several researchers (Hanassab, 2006; Lee \& Rice, 2007; Lee, 2007; Poyrazli \& Lopez, 2007; Sodowsky \& Plake, 1992) who showed that international students have been subjected to discrimination. This was especially true for non-European international students. Moreover, according to Lee (2007), international students perceived their experiences of discrimination as a part of earning an American 
degree and they have tended to normalize and tolerate this kind of treatment.

Related to this study, Muslim students have increasingly become targets for Islamophobia, especially after September 11, 2001 (Council on American-Islamic Relations, 2007). There are several studies in which Muslim students reported that they had experienced discrimination. For example $76 \%$ of young Arab Americans of traditional college age, 18 to 29 years, had experienced personal discrimination (Arab American Institute [AAI], 2007). Another study (Georgetown University, 2004) also indicated that a majority (59\%) of Muslims had not directly experienced anti-Muslim discrimination since the 9/11 attacks, but that most (57\%) had known someone who had. The participants also noted that most of the incidents of discrimination had occurred in a work or school setting, or in their own neighbourhoods. This same study showed that a quarter $(26 \%)$ of Muslim Americans had been victims of racial profiling since the 9/11 attacks. Other problems Muslim students have experienced include: a lack of a safe space for prayer (Blumenfeld, 2006; Nasir \& Al Amin, 2006), academic obligations that overlap with prayer times (Speck, 1997), feeling obligated to be representatives of their religion and culture (Nasir \& Al Amin, 2006), and classroom discussions which have led to the expression of ridicule and discrimination toward Muslims and Islam because of not being monitored properly by professors (Speck, 1997). Sodowsky and Plake (1992) found that Muslim students reported more discrimination than any other religious group. Hanassab (2006) also found that students from the Middle East and Africa reported the highest amount of discrimination.

The findings from Abukhattala's qualitative study (2004), which investigated educational and cultural adjustment of ten Arab Muslims students in Canadian university classrooms, were consistent with the above studies. All participants reported that they had experienced negative attitudes against Islam, Muslims and Arabs from their non-Muslim peers. An investigation, by the Canadian Federation of Students (2007) also produced similar findings regarding the situation of Muslim university students in Canada. According to the Canadian Federation of Students' investigation report the worst examples of systemic Islamophobia were observed in classrooms. Professors and other students made ignorant and hurtful comments that reflected stereotypes of Islam and of Muslims. The discussions about Islam made Muslim students feel uncomfortable, intimidated, undervalued, and singled-out. A conclusion reached was as follows: "The instances of Islamophobia are not isolated; discrimination toward Muslim students is a systemic feature of Ontario's post-secondary education system"( $\mathrm{p}$. 27).

While it is possible to think of the problems, above, as particular to and limited to Ontario higher education institutions, this is probably not the case. The results of the Survey of International Students (Prairie Research Associates, 2009, p. 56) supported the picture drawn by the former study and implied that this problem was not a local issue. Data collected from 22 universities and four colleges showed that $29 \%$ of Middle Eastern and North African students had experienced some form of racism or discrimination as an international student in Canada. According to Pew Research Center's Forum on Religion \& Public Life (2009), all countries in the Middle East and North Africa, except Israel, were Muslim majority countries.

There are data that reflect the existence of discrimination at the institutional levels, as well. For example, from the results of 2005 IAU Global Survey, regarded the geographic priority attributed to different regions by higher education institutions for internationalization efforts (Knight, 2006) as follows: Europe (37\%), Asia Pacific (24\%), North America (19\%), Latin America, and Caribbean (9\%), Africa (7\%), Middle East (5\%). In other words, it may be inferred that universities do not consider some regions as valuable as the others for internationalization efforts. We can see a similar tendency in the results of the 2009 and 2014 surveys (Egron-Polak \& Hudson, 2010, 2014). Although a strong pattern of intra-regional priority within internationalization policies was observed, this was not enough to explain all parts of this picture. For example, according to the results of the 2005 (Knight, 2006) and 2009 (Egron-Polak \& Hudson, 2010) surveys for European institutes, Asia Pacific region had more priority than did the Middle East and Africa regions which are geographically closer to Europe. For North American institutes, the Asia Pacific region countries have higher priority than do countries in Latin America and the Caribbean regions. As Hudzik (2011) offered:

Some countries and regions already draw considerable attention because of their burgeoning economies and growing position in the global market place; they are significant suppliers of labor or raw materials, or a source of products. Some others generate interest negatively by being a nexus of instability, unrest, and radicalism that can serve as a base for projecting mass violence around the world. And in other cases, interest is created by cultural appeal or because their higher education systems and research and development capacities offer us both challenge and opportunity in the world of ideas and technology. Unquestionably, some nations or regions will have more than one of these compelling characteristics. (p. 20) 
Whatever the reasons, it is obvious that the Middle East, Africa, Latin America and the Caribbean regions were kept out of scope by higher education institutes from all over the world.

Fairness is concept closely related with discrimination (Harris, Lievens \& Van Hoye, 2004). To perceive a situation as discriminative is dependent on the fairness perception of the person who decides. People first evaluate the fairness of the procedure and compare the allocations that they were given with others. If they decide that that a particular act is unfair they will describe the situation as discriminative. Discrimination is also an indicator of interactional unfairness (Houston \& Bettencourt, 1999).

Besides the discrimination issue, fairness perception is also important in other ways. For example, students see fairness as one of the top characteristics for what makes a good teacher (Rodabaugh, 1996; Stronge, 2007; Thompson, J. Greer, \& B. Greer, 2004). If students perceive that teachers are not concerned with fairness they are likely to engage in resistance or verbal aggressiveness, enact revenge, or communicate in a deceptive manner (Chory-Assad, 2002; Chory-Assad \& Paulsel, 2004a,b; Paulsel \& Chory-Assad, 2005; Paulsel, Chory-Assad, \& Dunleavy, 2005). The experience of injustice may have a negative impact on students' personalities and sense of coherence, reduce their motivation, and consequently impair their performance (Gage \& Berliner, 1996). Perceived injustice may even shape students' worldviews regarding a just or unjust society (Dar, Erhard, \& Resh, 1998). Rodabaugh (1996) emphasized the same issue as follows:

When the institution upholds fairness in as many ways as possible, students receive the message that the world can be, and should be, a fair place. The world is not always fair, of course, but colleges should be in the business of demonstrating to students that the ideal of fairness can be an organizing principle for social groups and institutions. Given a steady dose of fairness for four years or more, students just might enter society with a heightened commitment to a just social order. (p. 44)

On the other hand, fairness perception is attributed with enhancing student motivation and effort (Chory-Assad, 2002), students' evaluations of the course and the professor (Tata, 1999), the quality of the student-professor relationship (Walsh \& Maffei, 1994; Wendorf \& Alexander, 2004), compliance with class rules and satisfaction with one's grade (Colquitt, 2001), student learning outcomes (Walsh \& Maffei 1994), students' expectancy beliefs and affective learning which are predictors of students' learning behaviours (Vallade, Martin \& Weber, 2014), transaction-specific satisfaction regarding instructors' responses to rhetorical dissent and positive long-term classroom outcomes (Holmgren \& Bolkan, 2014). These variables are important and desirable qualities of a supportive organizational culture for internationalization as well as, more generally, for a healthy academic atmosphere.

Although fairness expectation may be considered a universal value, there are several studies (i.e., Birnbaum-More \& Wong, 1995; Itoi, Ohbuchi, \& Fukuno, 1996; Leung, 1987; Leung, Bond, Carment, Krishnan, \& Liebrand, 1990, Leung \& Lind,1986; Steiner \& Gilliland, 1996; Tata, 2005) which show that people may perceive the fairness level of practices differently and that they may react to unfairness differently in different countries, due to the influence of their cultures. Muslim students are one of the groups who have complained of being targeted for Islamophobia, discrimination, and unfairness. To investigate their fairness perception and experiences provided us with a deeper understanding with which to offer recommendations for the development of effective policies. The knowledge of Muslim students' fairness perceptions is deemed useful for efforts aimed at establishing supportive university settings; wherein, students feel they are valued and respected. Therefore, this article explores the perceptions and experiences of fairness amongst Muslim post-secondary students in order to gain insights for internationalization policy making in post-secondary education.

\section{Method}

This article represents the quantitative aspect of a larger mixed methods study. The findings presented are based on the data collected by a web survey consisting of 21 questions. The survey was piloted and modified prior to its use with the selected respondents. There were ten questions aimed at collecting demographic data and 11 substantive questions, designed to respond to research purposes, using a seven point Likert scale. Two questions were related to the frequency of unfairness experiences and their impact level. For the first question: 1, on the scale, was to indicate that they had not encountered, observed or experienced any unfairness in their university at all, while 7 on the scale was to indicate that they had encountered, observed or experienced unfairness very frequently. For the second question, 1 on the scale was to show that participant had not been impacted at all from the unfairness they may have encountered, observed, or experienced in their university, while 7 on the scale was to indicate that he or she had been impacted extremely from the unfairness he or she may have encountered, observed or experienced unfairness very frequently. Participants were asked to evaluate fairness levels of four settings: the university in which the participant was studying; Canada; the country the participant culturally 
identified with; and the World. Perceived fairness levels of these settings for Muslims and for non-Muslims questions were asked separately. To determine the fairness levels of the settings, and personal fairness levels scoring was reversed. That is, if a participant marked 1 on a scale, it was scored as 7 .

The responding participants were volunteer Muslim students recruited from within the network of 134 student organizations, from 32 Canadian University, local and national Islamic organizations, and from members of Muslim student groups on social media. The organizations were religious or cultural associations, clubs or societies (i.e., Muslim Student Association (MSA), Iranian Student Association, Pakistani Student Association, Indonesian Student Association, Turkish Student Association, Malaysian-Singaporean Students Club, etc.). After responses were received from 17 student organizations (nine of them MSA's) at 12 Canadian universities, each administrator of the organizations was sent an e-mail with a brief description of the study and the link to the survey, which the administrators then forwarded to their members and students in their network using their e-mail lists to assist in recruitment. Lastly, snowball sampling was also utilized by soliciting referrals from initial subjects to reach additional research subjects. Research participants were asked to forward the survey link to other known Muslim students. In addition, the invitation letters were sent to some local and national Islamic organizations and Muslim student groups organized on Facebook to reach Muslim university students in their networks (the respondent-participant number reached 189). Detailed information about participants is presented in Table 1.

Descriptive and inferential statistics were used to analyze the demographic characteristics of the survey respondents and their perceptions regarding the fairness level of various environments. Of course, all ethical responsibilities were fulfilled for the study through an approved Research Ethics Board protocol.

\section{Results}

First demographic data describe the participants and then findings regarding fairness experiences and perception of fairness are presented below in accordance with research questions.

\subsection{Demographic Data}

One hundred eighty-nine Muslim Students participated in the survey. Table 1 provides the summary of the demographic data regarding the respondents.

Table 1. Demographic data regarding nominal variables

\begin{tabular}{|c|c|c|c|c|}
\hline Variable & Groups & Frequency & Percent & $\begin{array}{l}\text { Valid } \\
\text { Percen }\end{array}$ \\
\hline \multirow{4}{*}{ Gender } & Male & 81 & 42.9 & 43.8 \\
\hline & Female & 104 & 55.0 & 56.2 \\
\hline & Missing & 4 & 2.1 & \\
\hline & Total & 189 & 100.0 & 100.0 \\
\hline \multirow{7}{*}{ Field of Study } & Health and Human Sciences & 45 & 23.8 & 24.2 \\
\hline & Natural Sciences and Engineering & 54 & 28.6 & 29.0 \\
\hline & Social Studies, Humanities and Fine & 52 & 27.5 & 28.0 \\
\hline & Arts & 35 & 18.5 & 18.8 \\
\hline & Other & 3 & 1.6 & \\
\hline & Missing & 189 & 100.0 & 100.0 \\
\hline & Total & & & \\
\hline \multirow{5}{*}{ Level of Study } & Undergraduate & 123 & 65.1 & 65.8 \\
\hline & Graduate & 58 & 30.7 & 31.0 \\
\hline & Other & 6 & 3.2 & 3.2 \\
\hline & Missing & 2 & 1.1 & \\
\hline & Total & 189 & 100.0 & 100.0 \\
\hline
\end{tabular}




\begin{tabular}{|c|c|c|c|c|}
\hline \multirow{5}{*}{ Legal Status } & International Student & 41 & 21.7 & 21.9 \\
\hline & Canadian Citizen & 120 & 63.5 & 64.2 \\
\hline & Permanent resident & 26 & 13.8 & 13.9 \\
\hline & Missing & 2 & 1.1 & \\
\hline & Total & 189 & 100.0 & 100.0 \\
\hline \multirow{4}{*}{ Country Spent Majority of Life } & Out of Canada & 96 & 50.8 & 51.6 \\
\hline & Canada & 90 & 47.6 & 48.4 \\
\hline & Missing & 3 & 1.6 & \\
\hline & Total & 189 & 100.0 & 100.0 \\
\hline \multirow{6}{*}{ Nationality } & Non-Canadian & 121 & 64.0 & 65.4 \\
\hline & Canadian & 36 & 19.0 & 19.5 \\
\hline & Mixed (Canadian and another & 28 & 14.8 & 15.1 \\
\hline & nationality) & 4 & 2.1 & \\
\hline & Missing & 189 & 100.0 & 100.0 \\
\hline & Total & & & \\
\hline \multirow{5}{*}{$\begin{array}{l}\text { Country } \\
\text { with }\end{array}$} & Other Countries & 126 & 66.7 & 68.5 \\
\hline & Canada & 28 & 14.8 & 15.2 \\
\hline & Mixed with Canada or Unsure & 30 & 15.9 & 16.3 \\
\hline & Missing & 5 & 2.6 & \\
\hline & Total & 189 & 100.0 & 100.0 \\
\hline
\end{tabular}

Eighty-one (43.8\%) of the respondents were male, and $104(56.2 \%)$ respondents were female. A similar percentage of the respondents were studying in the fields of Natural Sciences and Engineering $(28.6 \%)$ and Social Studies, Humanities and Fine Arts (27.5\%). One hundred and twenty-three (65.8\%) of the respondents were undergraduate students, whereas $58(31.0 \%)$ of them were graduate students. One hundred twenty $(65.2 \%)$ of the participants were Canadian citizen, but only 28 (15.2\%) students reported that they culturally identified with Canada and $30(16.3 \%)$ participants stated that they identified with two countries, including Canada (or they were not sure). Similarly, $121(65.4 \%)$ students reported their nationality as one of the non-Canadian nationalities. The number of students who spent the majority of their lives in Canada and out of Canada were close to the same: $96(51.6 \%)$ and $90(48.4 \%)$, respectively. The data show that 34 different nationalities were claimed by the participants. Similarly, 35 different cultures were declared by the participants. Mixed answers also had diversity. Canadian identity was stated, together with various other countries' identities, in participants' responses.

Descriptive statistics regarding ordinal variables of the study are given in Table 2:

Table 2. Descriptive statistics regarding ordinal variables

\begin{tabular}{lccccc}
\hline & N & Minimum & Maximum & Mean & Std. Deviation \\
\hline Age (years) & 184 & 17.00 & 46.00 & 24.13 & 5.96 \\
The time spent in Canada (years) & 184 & 1.00 & 34.00 & 10.82 & 7.34 \\
Age at arrived in Canada (years) & 183 & .00 & 42.00 & 13.31 & 10.32 \\
\hline
\end{tabular}

As can be seen in Table 2, the average age of the participants was 24.1; average time spent in Canada was 10.8 years; and average arrival age in Canada was age 13.3. According to the results, participants seem heterogeneous in terms of age, the time spent in Canada and age of arrived in Canada.

\subsection{Unfairness Experiences and Their Impact}

The descriptive statistics regarding the frequency of unfair situations Muslim students experienced or faced 
within their university and the perceived impact level of these situations is presented in Table 3, Table 4 and Table 5 .

According to the data given in Table 3,69.6\% of respondents reported that they had encountered, observed or experienced unfairness at least once in their university in the previous academic year. The results also show that these incidents were not very frequent. Only about $9 \%$ percent of participants responded with 5 and 6 on the seven point scale.

Table 3. Frequency distribution of encountered unfairness

\begin{tabular}{llllll}
\hline & & Frequency & Percent & Valid Percent & Cumulative Percent \\
\hline Not at all & 1 & 55 & 29.1 & 30.4 & 30.4 \\
& 2 & 52 & 27.5 & 28.7 & 59.1 \\
& 3 & 43 & 22.8 & 23.8 & 82.9 \\
& 4 & 15 & 7.9 & 8.3 & 91.2 \\
& 5 & 13 & 6.9 & 7.2 & 98.3 \\
Very Frequent & 6 & 3 & 1.6 & 1.7 & 100.0 \\
& 7 & 0 & 0 & 0 & \\
& Total & 181 & 95.8 & 100.0 & \\
Total & Missing & 8 & 4.2 & & \\
\hline
\end{tabular}

In Table 4 the personal impact level of these unfairness incidents is presented.

Table 4. Frequency distribution of perceived impact level of encountered fairness

\begin{tabular}{llllll}
\hline & & Frequency & Percent & Valid Percent & Cumulative Percent \\
\hline Not impacted at all & 1 & 74 & 39.2 & 40.9 & 40.9 \\
& 2 & 44 & 23.3 & 24.3 & 65.2 \\
& 3 & 25 & 13.2 & 13.8 & 79.0 \\
& 4 & 16 & 8.5 & 8.8 & 87.8 \\
& 5 & 15 & 7.9 & 8.3 & 96.1 \\
Extremely impacted & 6 & 4 & 2.1 & 2.2 & 98.3 \\
& 7 & 3 & 1.6 & 1.7 & 100.0 \\
Missing & Total & 181 & 95.8 & 100.0 & \\
Total & & 8 & 4.2 & & \\
\hline
\end{tabular}

When the frequency distribution is reviewed, it may be seen that, in addition to participants who had not encountered, observed or experienced any unfairness, around $10 \%$ of participants reported that they had not been impacted from the unfairness that they had faced. However, 59.1\% of the participants stated that they had been impacted from the unfairness at some level. The impact level for $12 \%$ of the participants was high.

After scoring the responses to these two questions, obtained distributive statistics are provided in the Table 5. 
Table 5. Descriptive statistics regarding encountered unfairness and their impact level

\begin{tabular}{llllll}
\hline & $\mathrm{N}$ & Minimum & Maximum & Mean & Std. Deviation \\
\hline Frequency of Encountered Unfairness & 181 & 1 & 6 & 2.38 & 1.284 \\
Impact Level of Encountered Unfairness & 181 & 1 & 7 & 2.33 & 1.523 \\
\hline
\end{tabular}

In addition to the descriptive statistics, the correlation between the frequency of encountered unfairness and the impact level of encountered unfairness was also counted. The obtained Pearson correlation coefficient value (.74) was significant at the 0.01 level (two tailed). This positive correlation means that the participants who encountered unfairness more frequently in their university were impacted from the unfairness more, as well.

3.3 Fairness Perceptions of Muslim Students in Various Settings

Descriptive statistics regarding these data are presented in Table 6.

Table 6. Descriptive statistics for perceived fairness levels of various settings

\begin{tabular}{|c|c|c|c|c|c|}
\hline & $\mathbf{N}$ & Minimum & Maximum & Mean & $\begin{array}{c}\text { Std. } \\
\text { Deviation }\end{array}$ \\
\hline Fairness level of their university (for Muslims) & 183 & 1 & 7 & 6.26 & 1.189 \\
\hline Fairness level of Canada (for Muslims) & 183 & 1 & 7 & 5.33 & 1.335 \\
\hline $\begin{array}{l}\text { Fairness level of the country culturally } \\
\text { identified with (for Muslims) }\end{array}$ & 183 & 1 & 7 & 5.27 & 1.825 \\
\hline Fairness level of the world (for Muslims) & 183 & 1 & 7 & 3.17 & 1.537 \\
\hline $\begin{array}{l}\text { Fairness level of their university (for } \\
\text { non-Muslims) }\end{array}$ & 183 & 3 & 7 & 6.56 & .795 \\
\hline Fairness level of Canada (for non-Muslim) & 184 & 2 & 7 & 6.33 & .948 \\
\hline $\begin{array}{l}\text { Fairness level of the country culturally } \\
\text { identified with (for non-Muslims) }\end{array}$ & 180 & 1 & 7 & 5.08 & 1.885 \\
\hline Fairness level of the world for (non-Muslims) & 183 & 1 & 7 & 5.27 & 1.631 \\
\hline
\end{tabular}

According to the data, Muslim students perceived their university as the fairest setting for both Muslims $(\mathrm{M}=6.26)$ and non-Muslims $(\mathrm{M}=6.56)$; while the World was perceived as the least fair setting for Muslims $(\mathrm{M}=3.17)$. A bar graph (Figure 1) is based on the data in the Table 6 .

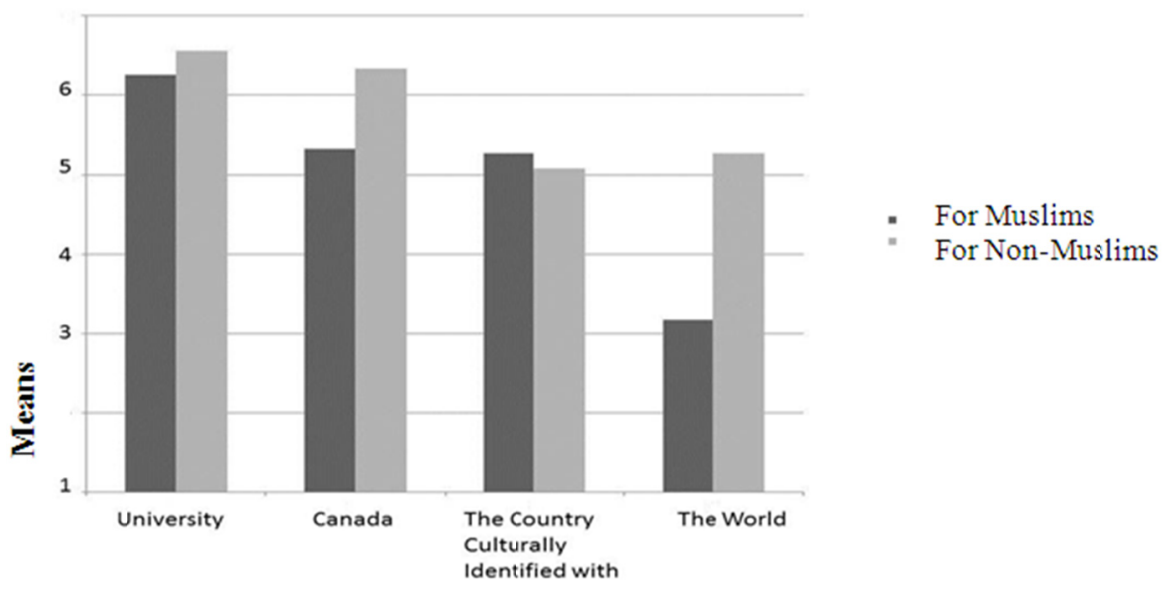

Figure 1. Perceived fairness levels of various settings 
Paired-sample $t$ tests were employed to determine whether the differences in the means observed in the descriptive statistics are significant or not. The results are given in Table 7.

Table 7. Paired sample t-Test results (setting comparisons)

\begin{tabular}{|c|c|c|c|c|c|c|c|c|}
\hline \multirow[t]{2}{*}{ Pairs } & \multirow[t]{2}{*}{ Mean } & \multirow[t]{2}{*}{$\begin{array}{c}\text { Std. } \\
\text { Deviation }\end{array}$} & \multirow[t]{2}{*}{$\begin{array}{l}\text { Std. } \\
\text { Error } \\
\text { Mean }\end{array}$} & \multicolumn{2}{|c|}{$\begin{array}{c}95 \% \text { Confidence } \\
\text { Interval of the } \\
\text { Difference } \\
\end{array}$} & \multirow[t]{2}{*}{$\mathbf{t}$} & \multirow[t]{2}{*}{ df } & \multirow[t]{2}{*}{$\begin{array}{c}\text { Sig. } \\
\text { (2-tailed) }\end{array}$} \\
\hline & & & & Lower & Upper & & & \\
\hline $\begin{array}{l}\text { University - Canada } \\
\text { (for Muslims) }\end{array}$ & .93 & 1.35 & .100 & .737 & 1.131 & 9.344 & 181 & .000 \\
\hline \multicolumn{9}{|l|}{ University - Country } \\
\hline $\begin{array}{l}\text { Culturally Identified } \\
\text { with (for Muslims) }\end{array}$ & 1.01 & 1.90 & .141 & .727 & 1.284 & 7.131 & 181 & .000 \\
\hline $\begin{array}{l}\text { University-The World } \\
\text { (for Muslims) }\end{array}$ & 3.09 & 1.87 & .139 & 2.820 & 3.367 & 22.308 & 181 & .000 \\
\hline \multicolumn{9}{|l|}{ Canada - Country } \\
\hline \multicolumn{9}{|l|}{ Culturally Identified } \\
\hline \multicolumn{8}{|l|}{ Canada- The World } & .000 \\
\hline \multicolumn{9}{|l|}{ Country Culturally } \\
\hline World (for Muslims) & 2.10 & 2.20 & .163 & 1.782 & 2.427 & 12.883 & 181 & .000 \\
\hline \multicolumn{8}{|l|}{ University - Canada } & .000 \\
\hline \multicolumn{9}{|l|}{ University - Country } \\
\hline $\begin{array}{l}\text { Culturally Identified } \\
\text { with (for non-Muslims) }\end{array}$ & 1.50 & 1.97 & .148 & 1.206 & 1.789 & 10.139 & 178 & .000 \\
\hline \multicolumn{8}{|l|}{ University-The World } & .000 \\
\hline \multicolumn{9}{|l|}{ Canada - Country } \\
\hline \multicolumn{8}{|l|}{ Culturally Identified } & .000 \\
\hline \multicolumn{9}{|l|}{ Canada- The World } \\
\hline \multicolumn{9}{|l|}{ Country Culturally } \\
\hline $\begin{array}{l}\text { Identified with - The } \\
\text { World (for } \\
\text { non-Muslims) }\end{array}$ & -.20 & 2.32 & .173 & -.542 & .142 & -1.153 & 179 & .250 \\
\hline
\end{tabular}

As seen in Table 7, almost all the differences between perceived fairness levels of various setting were significant except in two cases. According to Muslim students, their universities' fairness levels are significantly higher than fairness levels of other settings for Muslims and non-Muslims. They perceived Canada as a fair place for Muslims and non-Muslims if it was compared to the World. They did not see any difference between the 
fairness levels of Canada and the country that they culturally identified with. Muslim students also did not perceive any significant difference between the fairness levels of the country they had identified with and the World for non-Muslims.

Another group of paired-sample $t$ test was employed to compare Muslim students' perception regarding fairness levels of the settings for Muslims and non-Muslims (see Table 8).

Table 8. Paired sample t-Test results (for Muslims-Non-Muslims Comparisons)

\begin{tabular}{|c|c|c|c|c|c|c|c|c|}
\hline & \multirow{3}{*}{ Mean } & \multirow{3}{*}{$\begin{array}{c}\text { Std. } \\
\text { Deviation }\end{array}$} & \multirow{3}{*}{$\begin{array}{l}\text { Std. } \\
\text { Error } \\
\text { Mean }\end{array}$} & \multicolumn{2}{|c|}{ 95\% Confidence } & \multirow{3}{*}{$\mathbf{t}$} & \multirow{3}{*}{ Df } & \multirow{3}{*}{$\begin{array}{l}\text { Sig. } \\
\text { (2-taile } \\
\text { d) }\end{array}$} \\
\hline & & & & $\begin{array}{r}\text { Inter } \\
\text { Diff }\end{array}$ & $\begin{array}{l}\text { of the } \\
\text { ence }\end{array}$ & & & \\
\hline & & & & Lower & Upper & & & \\
\hline $\begin{array}{l}\text { University for Muslims - } \\
\text { for Non-Muslims }\end{array}$ & -.302 & 1.162 & .086 & -.472 & -.132 & -3.509 & 181 & .001 \\
\hline $\begin{array}{l}\text { Canada for Muslims - } \\
\text { for Non-Muslims }\end{array}$ & -.995 & 1.256 & .093 & -1.178 & -.811 & -10.714 & 182 & .000 \\
\hline $\begin{array}{l}\text { The Country Culturally } \\
\text { Identified with for } \\
\text { Muslims - for }\end{array}$ & .189 & 2.244 & .167 & -.141 & .519 & 1.129 & 179 & .260 \\
\hline Non-Muslims & & & & & & & & \\
\hline $\begin{array}{l}\text { The World for Muslims - } \\
\text { for Non-Muslims }\end{array}$ & -2.115 & 1.965 & .146 & -2.403 & -1.828 & -14.526 & 181 & .000 \\
\hline
\end{tabular}

Since three of the four $t$ tests results were found statistically significant, it may be said that Muslim students perceived their university, Canada and the World as more fair for non-Muslims. These respondents not perceive any difference between the fairness levels of the country that they had culturally identified with, for either Muslims or non-Muslims.

The results regarding the fairness perception of Muslim students in various settings can be summarized by listing the settings according to their perceived fairness levels, from the highest to lowest: (1) Their university, (2) Canada and the country Muslim students culturally identified with, and (3) The World. For non-Muslims, the respondents perceived this with slight differences: (1) Their university, (2) Canada, (3) The World and the country Muslim students culturally identified with. According to this result, Muslim students perceptions related to the fairness levels of their university, Canada, and the World were more optimistic those held for non-Muslims. They perceived these settings as more fair for non-Muslims than for Muslims.

\section{Discussion}

These findings showed that while universities are not free from unfairness; Canadian universities were not seen by attending respondents as an inherently unfair. The majority of participants reported that they had encountered, observed, or experienced unfairness at least once and further indicated that they had been impacted, on some level, by the unfairness at their university during the previous academic year. This finding is consistent with other related research (i.e., Abukhattala, 2004; Canadian Federation of Students, 2007).

In this study, Muslim students perceived that their university was the fairest setting; although the majority encountered, observed, or experienced some unfairness. Since universities are the most refined settings among others this finding should not be surprising. It might have been anticipated that biases, stereotypes, ignorance or racism would not be prevalent at a university campus because of the university culture of highly educated people with whom students interact. Hopkins' (2011) study, conducted in the United Kingdom, drew a similar picture. Muslim student participants in Hopkins' study had two different opinions that could be seen as contradictory. According to his findings, participants advocated that their university campus was a liberal and tolerant place compared to outside the university; but they also saw the university as a marginalising, culturally exclusive and institutionally discriminatory place. In Seggie's and Sanford's (2010) similar study, with participants who were Muslim female students from a predominantly Christian university in the United States, resulted in findings 
which indicated perceptions of the university climate as welcoming and supportive. However, the participants also reported some examples of marginalization, prejudice and discomfort. Likewise, in our study, participants tended to see their university as a fair place, in spite of the existence of unfair incidents. This approach may reflect that they saw unfairness incidents as exceptional and as such these did not decrease the overall fairness level of their university.

The perceptions of Muslim students regarding the fairness level of Canada were optimistic, although they had experienced problems. Muslim students did not perceive any differences between fairness levels of Canada and the country with which they had culturally identified and these students did not attribute unfairness to the whole society. Muslim students' positive opinions regarding the fairness level of Canada in this study were consistent with Environics Research Group's (2006) survey which indicated that a majority (77\%) of Muslim-Canadian participants agreed that Muslims are better treated in Canada when compared to treatment in other Western countries; although $31 \%$ of participants in the survey stated that they had experienced discrimination because of their race, ethnicity or religion in the previous two years.

When it comes to the fairness level of the World, Muslim students' perceptions radically changed from positive to negative. The means of perceived fairness levels of various settings (university $=6.26$, Canada $=5.33$, the country culturally identified with $=5.27$, the World $=3.17$ ) showed that our participants perceived the World as the most unfair of these settings. Students seemed quite pessimistic about the fairness level of the World for Muslims. This pessimism was observed in comparisons with the situation of non-Muslims as well. Participants saw the university, Canada and the World settings as more fair for non-Muslims. Perceived Western double standards against Muslims (i.e., Ahmad, 2012; Al Aswany, 2009; Ayoob, 2012, Masud, 1998), especially in international relations, might lead to these results. Further research is necessary to investigate these perceptions.

\section{Conclusion}

In conclusion, the findings from the research showed that the majority of participating Muslim students had encountered unfairness and that they were impacted from the experiences of unfairness in the previous academic year. The good news for policy makers or administrators is that the Muslim students in this study perceived Canada and Canadian universities to be fair places for Muslims. From a market model perspective, that means a good reputation and, in turn, another positive attraction factor for international Muslim students. From an idealistic perspective, this perception contributes to the view that there is a positive climate in place for interculturalization such as will support the enhancement of life capabilities for all students. Yet, fairness perception is not a permanent structure; rather it is highly fragile. Even one single incident may completely change such a positive image. Continuous attention and effort are necessary to sustain the positive fairness perceptions of Canadian universities and Canada for Muslim students. The existence of the unfairness experiences of Muslim students explored in this study clearly threatens the positive image of Canadian universities. While universities may not be the source for the attitudes or misinformation that create conditions of unfairness, universities have responsibility to ameliorate this problem. Established opportunities to interact with Muslims may be one measure to change negative attitudes. The following survey results are considered as a support for this suggestion.

Canadians' views of Islam improve the more frequent their personal contact with Muslims. Of those who encounter Muslims often, a large majority (70\%) report positive impressions of Islam, compared with just one in five (22\%) who are negative about the faith. Among those who encounter Muslims rarely or never in their own lives, just over a third (36\%) express positive impressions of Islam, while half (49\%) are negative about it. (Environics Research Group, 2006, p. 65)

One of the limitations of this study was the voluntary nature of participation. Respondents were self-selected to complete the survey and this may have created a non-response bias. Those students who did choose to complete to the survey may have felt more strongly, one way or another, than might those who did not respond. The results regarding fairness experiences of participants showed that the sample not only included participants who had been subjected to unfairness but also Muslim students who had not been faced with any unfairness in their university. However, the percentage of Muslim students who experienced unfairness in the sample may have been higher or lower than in the general Muslim student population.

The selection of respondents does not assure representation and, therefore, generalization of finding is problematic. For example, Muslim students from a few Muslim majority countries such as Indonesia, Malaysia or some African countries were underrepresented in the sample. The Shia Muslims population was not proportionally represented in the sample.

Replicating this study, with a larger sample of Muslim students, may provide higher generalizability. For 
example, having more students from underrepresented nations in the sample would provide opportunities for comparison in examining national cultural differences.

\section{References}

Abukhattala, I. (2004). Educational and cultural adjustment of ten Arab Muslim students in Canadian university classrooms (Unpublished Doctoral Dissertation). McGill University. Montreal, QB.

Ahmad, S. (2012). Freedom of speech and Western double standards. Radiance Viewsweekly Web Edition, 27(1). Retrieved January 12, 2016, from http://www.radianceweekly.com/326/9411/let-us-refuse-to-be-provoked/ 2012-09-30/cover-story/story-detail/freedom-of-speech--and-western-double-standards.html

Al Aswany, A. (2009). Western hostility to Islam is stoked by double standards and distortion. The Guardian, Monday 20 July 2009.

Arab-American Institute. (2007). AAI/Zogby poll on Arab American experiences and identity shows increase in discrimination among young Arab Americans. Press release. Retrieved March 14, 2013, from http://www.aaiusa.org/page//Polls/r2007\%20AA\%20Identity\%20poll\%20 -\%20FINAL.pdf

Association of Universities and Colleges of Canada. (2007). Internationalizing Canadian campuses: Main themes emerging from the Scotiabank-AUCC workshop on excellence in internationalization at Canadian universities. Ottowa: AUCC.

Ayoob, M. (2012). Is Europe setting up clash between Muslims and the West? CNN Opinion. Retrieved from http://www.cnn.com/2012/02/03/opinion/ayoob-clash-muslims-and-west/index.html?hpt=hp_c3

Becket, N., \& Brookes, M. (2008). Assessing the international dimensions of degree programmes. In P. Kemp, \& R. Atfield (Eds.), Enhancing the international learning experience in business and management, hospitality, leisure, sport tourism (pp. 58-67). Newbury: Threshold Pres.

Berman, R., \& Cheng, L. (2001). English academic language skills: Perceived difficulties by undergraduate and graduate students, and their academic achievement. Canadian Journal of Applied Linguistics, 4(1-2), 25-40.

Birnbaum-More, P. H., Wong, G. Y. Y., \& Nils-Goran, O. (1995). Acquisition of managerial values in the People's Republic of China and Hong Kong. Journal of Cross-Cultural Psychology, 26(2), 255-273. http://dx.doi.org/10.1177/0022022195263003

Blumenfeld, W. J. (2006). Christian privilege and the promotion of 'secular' and not-so 'secular' mainline Christianity in schooling and the larger society. Equity and Excellence in Education, 39(3), 195-210. http://dx.doi.org/10.1080/10665680600788024

Canadian Federation of Students. (2007). Final report of the task force on needs of Muslim students. Toronto: CFS.

Chataway, C. J., \& Berry, J. W. (1989). Acculturation experiences, appraisal, coping, and adaptation: A comparison of Hong Kong Chinese, French, and English students in Canada. Canadian Journal of Behavioural Science, 21(3), 295-309. http://dx.doi.org/10.1037/h0079820

Cheng, L., Myles, J., \& Curtis A. (2004). Targeting language support for non-native English-speaking graduate students at a Canadian university. TESL Canada Journal, 21(2), 50-71. http://dx.doi.org/10.1177/1475240906065589

Chory-Assad, R. M. (2002). Classroom justice: Perceptions of fairness as a predictor of student motivation, $\begin{array}{llll}\text { learning, and aggression. } & \text { Communication }\end{array}$ http://dx.doi.org/10.1080/01463370209385646

Chory-Assad, R. M., \& Paulsel, M. L. (2004a). Antisocial classroom communication: Instructor influence and interactional justice as predictors of student aggression. Communication Quarterly, 52(2), 98-114. http://dx.doi.org/10.1080/01463370409370184

Chory-Assad, R. M., \& Paulsel, M. L. (2004b). Classroom justice: Student aggression and resistance as reactions to perceived unfairness. Communication Education, 53(3), 253-273. http://dx.doi.org/10.1080/0363452042000265189

Colquitt, J. A. (2001). On the dimensionality of organizational justice: A construct validation of a measure. Journal of Applied Psychology, 86(3), 386-400. http://dx.doi.org/10.1006/obhd.2001.2958

Council on American-Islamic Relations. (2007). "Islamophobia". Retrieved March 15, 2013, from www.cair.com/Issues/Islamophobia/Islamophobia.aspx 
Dar, Y., Erhard, R., \& Resh, N. (1998). Perceiving social cleavages and inequalities: The case of Israeli adolescents. Youth \& Society. 30(1), 32-58. http://dx.doi.org/10.1177/0044118X98030001002

De Wit, H. (2002). Internationalization of higher education in the United States of America and Europe: A historical, comparative, and conceptual analysis. Westport, CT: Greenwood Press.

Egron-Polak, E., \& Hudson, R. (2010). Internationalization of higher education: Global trends, regional perspectives. IAU 3 rd global survey. Paris: UNESCO House

Egron-Polak, E., \& Hudson, R. (2014). Internationalization of higher education: Growing expectaions, fundamental values. IAU 4th global survey (Executive Summary). Retrieved January 12, 2016, from http://www.iau-aiu.net/sites/all/files/IAU-4th-GLOBAL-SURVEY-EXECUTIVE-SUMMARY.pdf

Environics Research Group. (2006). FOCUS CANADA: The pulse of Canadian public opinion, Report 2006-4. Ottowa: Environics Research Group Limited.

Gage, N., \& Berliner, D. (1996). Educational psychology (6th ed.). Boston, MA: Houghton, Mifflin.

Georgetown University. (2004). Georgetown announces release of 2004 American Muslim poll press release. Retrieved January 12, 2016, from http://explore.georgetown.edu/news/?ID=1310

Grayson, J. P. (2008). The experiences and outcomes of domestic and international students at four Canadian universities. Higher Education Research \& Development, 27(3), 215-230. http://dx.doi.org/10.1080/07294360802183788

Green, M. F. (2005). Internationalization of U.S. Higher Education: A Student Perspective. Washington, D.C.: American Council on Education.

Green, M. F., \& Olson, C. L. (2003). Internationalizing the campus: A user's guide. Washington, DC: American Council on Education.

Hanassab, S. (2006). Diversity, international students and perceived discrimination: Implications for educators and counsellors. Journal of Studies in International Education, 10(2), 157-172. http://dx.doi.org/10.1177/1028315305283051

Harari, M. (1989). Internationalization of higher education: Effecting institutional change in the curriculum and campus. Long Beach, CA: Center for International Education, California State University.

Harris, M. M., Lievens, F., \& Van Hoye, G. (2004). "I think they discriminated against me": Using prototype theory and organizational justice theory for understanding perceived discrimination in selection and promotion situations. International Journal of Selection and Assessment, 12(1/2), 54-65. http://dx.doi.org/10.1111/j.0965-075X.2004.00263.x

Holmgren, J. L. \& Bolkan, S. (2014). Instructor responses to rhetorical dissent: Student perceptions of justice $\begin{array}{llll}\text { and classroom outcomes. Communication } & \text { Education, }\end{array}$ http://dx.doi.org/10.1080/03634523.2013.833644

Hopkins, P. (2011). Towards critical geographies of the university campus: Understanding the contested experiences of Muslim students. Transactions of the Institute of British Geographers, 36(1), 157-169. http://dx.doi.org/10.1111/j.1475-5661.2010.00407.x

Houston, M. B., \& Bettencourt, L. A. (1999). But that's not fair! An exploratory study of student perceptions of $\begin{array}{llll}\text { instructor fairness. Journal of Marketing } & \text { Education, 21(2), 84-96. }\end{array}$ http://dx.doi.org/10.1177/0273475399212002

Hudzik, J. (2011). Comprehensive Internationalisation, from concept to action. Washington, D.C.: NAFSA.

Huyn, J., Quinn, B., Madon, T., \& Lustig, S. (2007). Mental health need, awareness, and use of counseling services among international graduate students. Journal of American College Health, 56(2), 109-118. http://dx.doi.org/10.3200/JACH.56.2.109-118

Itoi, R., Ohbuchi, K., \& Fukuno, M. (1996). A cross-cultural study of preference of accounts: Relationship closeness, harm severity, and motives of account making. Journal of Applied Social Psychology, 26(10), 913-934. http://dx.doi.org/10.1111/j.1559-1816.1996.tb01117.x

Jiang, X. (2008). Towards the internationalisation of higher education from a critical perspective. Journal of Further and Higher Education, 32(4), 347-358. http://dx.doi.org/10.1080/03098260701728500

Knight, J. (1994). Internationalization: Elements and checkpoints (CBIE Research No. 7). Ottawa, ON: Canadian Bureau for International Education. 
Knight, J. (2006). Key results: 2005 IAU global survey on internationalization of higher education. Retrieved January 12, 2016, from http://www.iau-aiu.net/sites/all/files/Key_results_2005_1.pdf

Knight, J. (2008). Higher education in turmoil: The changing world of internationalization. Rotterdam, Netherlands: Sense Publishers.

Knight, J. (2011). Five myths about internationalization. International Higher Education, 62(Winter), 14-15.

Leary, T. A. (2011). Supporting international students with first year transition into Canadian universities: Recommendations from Atlantic Canada (Unpublished Doctoral Dissertation). University of Calgary. Calgary, AB.

Lee, J. J. (2007). Bottom line-Neo-racism toward international students. About Campus, 11(6), 28-30. http://dx.doi.org/10.1002/abc.194

Lee, J., \& Rice, C. (2007). Welcome to America? International student perceptions of discrimination. Higher Education, 53(3), 381-409. http://dx.doi.org/10.1007/s10734-005-4508-3

Leung, K. (1987). Some determinants of reactions to procedural models for conflict resolution: A cross-national study. Journal of Personality and Social Psychology, 53(5), 898-908. http://dx.doi.org/10.1037/0022-3514.53.5.898

Leung, K., \& Lind, E. A. (1986). Procedural justice and culture: Effects of culture, gender, and investigator status on procedural preferences. Journal of Personality and Social Psychology, 50(6), 1134-1140. http://dx.doi.org/10.1037/0022-3514.50.6.1134

Leung, K., Bond, M. H., Carment, D. W., Krishnan, L., \& Liebrand, W. B. G. (1990). Effects of cultural femininity on preference for methods of conflict processing: A cross-cultural study. Journal of Experimental Social Psychology, 26(5), 373-388. http://dx.doi.org/10.1016/0022-1031(90)90064-S

Li, Y. (2001). A narrative inquiry of the intercultural and academic transitional experiences of four female Chinese students (Unpublished master's thesis). University of Alberta, Edmonton, AB.

Liang, S. X. (2004). Academic adaptation: Mainland Chinese students in graduate programs at a Canadian university (Unpublished Doctoral Dissertation). University of Calgary, Calgary, AB.

Lu, S. H., Dear, B. F., Johnston, L., Wootton, B. M., \& Titov, N. (2014). An internet survey of emotional health, treatment seeking and barriers to accessing mental health treatment among Chinese-speaking international students in Australia. Counselling Psychology Quarterly, 27(1), 96-108. http://dx.doi.org/10.1080/09515070.2013.824408

Masud, E. (1998). Double standard targets Muslim countries. The Wisdom Fund: News and Views. Retrieved January 12, 2016, from http://www.twf.org/News/Y1998/19980925-DoubleStandard.html

Mokua, R. N. (2012). Examining the adjustment problems of Kenyan international students attending colleges and universities in the United States (Unpublished Doctoral Dissertation). Morgan State University. Baltimore, MD.

Mori, S. (2000). Addressing the mental health concerns of international students. Journal of Counseling and Development, 78(2), 137-144. http://dx.doi.org/10.1002/j.1556-6676.2000.tb02571.x

Nasir, N. S., \& Al-Amin, J. (2006). Creating identity-safe spaces on college campuses for Muslim students. Change: The Magazine of Higher Learning, 38(2), 22-27. http://dx.doi.org/10.3200/CHNG.38.2.22-27

Nilsson, J. E., Berkel, L. A., Flores, L. Y., \& Lucas, M. S. (2004). Utilization rate and presenting concern of international students at a university counseling center: Implications for outreach programming. Journal of College Student Psychotherapy, 19(2), 49-59. http://dx.doi.org/10.1300/J035v19n02_05

Paulsel, M. L., \& Chory-Assad, R. M. (2005). Perceptions of instructor interactional justice as a predictor of student resistance. Communication Research Reports, 22(4), 283-291. http://dx.doi.org/10.1080/000368105000317565

Paulsel, M. L., Chory-Assad, R. M., \& Dunleavy, K. N. (2005). The relationship between student perceptions of instructor power and classroom justice. Communication Research Reports, 22(3), 207-215. http://dx.doi.org/10.1080/00036810500207030

Pew Research Center Forum on Religion \& Public Life. (2011). The future of the global Muslim population: Projections for 2010-2030. Washington D.C.: Pew Research Center. 
Pilote, A., \& Benabdeljalil, A. (2007). Supporting the success of international students in Canadian universities. Higher Education Perspectives, 3(2), 24-46.

Poyrazli, S. (2015). Psychological symptoms and concerns experienced by international students: outreach implications for counseling centers. Journal of International Students, 5(3), 306-312. Retrieved January 14, 2016, from http://files.eric.ed.gov/fulltext/EJ1060046.pdf

Poyrazli, S., \& Grahame, K. M. (2007). Barriers to adjustment: Needs of international students within a semi-urban campus community. Journal of Instructional Psychology, 34(1), 28-45.

Poyrazli, S., \& Lopez, M. D. (2007). An exploratory study of perceived discrimination and homesickness: A comparison of international students and American students. The Journal of Psychology, 141(3), 263-280. http://dx.doi.org/10.3200/JRLP.141.3.263-280

Prairie Research Associates. (2009). Canada first: The 2009 survey of international students. Ottowa: Canadian Bureau for International Education.

Rodabaugh, R. C. (1996). Institutional commitment to fairness in college teaching. In L. Fisch (Ed.), Ethical dimensions of college and university teaching (pp. 37-45). San Francisco: Jossey-Bass.

Seggie, F. N., \& Sanford, G. (2010). Perceptions of female Muslim students who veil: Campus religious climate. Race Ethnicity and Education, 13(1), 59-82. http://dx.doi.org/10.1080/13613320903549701

Sodowsky, G. R., \& Plake, B. S. (1992). A study of acculturation differences among international people and suggestions for sensitivity to within-group differences. Journal of Counseling \& Development, 71(1), 53-59. http://dx.doi.org/10.1002/j.1556-6676.1992.tb02171.x

Speck, B. W. (1997). Respect for religious differences: The case of Muslim students. New Directions for Teaching and Learning, 70 (summer), 39-46. http://dx.doi.org/10.1002/tl.7004

Steiner, D. D., \& Gilliland, S. W. (1996). Fairness reactions to personnel selection techniques in France and the

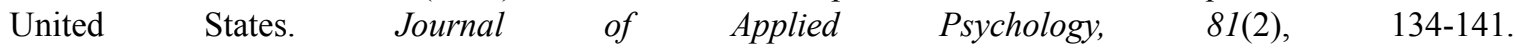
http://dx.doi.org/10.1037/0021-9010.81.2.134

Stier, J. (2004). Taking a critical stance toward internationalization ideologies in higher education: Idealism, instrumentalism and educationalism. Globalisation, Societies and Education, 2(1), 1-28. http://dx.doi.org/10.1080/1476772042000177069

Stronge, J. (2007). The qualities of effective teachers. Alexandria, VA: Association for Supervision and Curriculum Development.

Tata, J. (1999) Grade distributions, grading procedures, and students' evaluations of instructors: A justice perspective. The Journal of Psychology, 133(3), 263-271. http://dx.doi.org/10.1080/00223989909599739

Tata, J. (2005). The influence of national culture on the perceived fairness of grading procedures: A comparison of the United States and China. The Journal of Psychology, 139(5), 401-412. http://dx.doi.org/10.3200/JRLP.139.5.401-412

Thompson, S., Greer, J., \& Greer, B. (2004). Highly qualified for successful teaching: Characteristics every teacher should possess. Essays in Education. [Online] Retrieved March 15, 2013, from http://www.usca.edu/essays/vol102004/thompson.pdf

Trice, A. G. (2007). Faculty perspectives regarding graduate international students' isolation from host national students. International Education Journal, 8(1), 108-117.

Tung, W.-C. (2011). Acculturative stress and help-seeking behaviors among international students. Home Health Care Management \& Practice, 23, 383-385. http://dx.doi.org/10.1177/1084822311405454

Vallade, J. I., Martin, M. M., \& Weber, K. (2014). Academic entitlement, grade Orientation, and classroom justice as predictors of instructional beliefs and learning outcomes. Communication Quarterly, 62(5), 497-517. http://dx.doi.org/10.1080/01463373.2014.949386

Walsh, D. J., \& Maffei, M. J. (1994). Never in a class by themselves: An examination of behaviors affecting the student-professor relationship. Journal on Excellence in College Teaching, 5(2), 23-49. Retrieved March 18, 2014, from http://podnetwork.org/content/uploads/V7-N2-Walsh-Maffei.pdf

Wendorf, C.A., \& Alexander, S. (2005). The influence of individual and class level fairness related perceptions on student satisfaction. Contemporary Educational Psychology, 30(2), 190-206. http://dx.doi.org/10.1016/j.cedpsych.2004.07.003 
Wilson, G. P. (2011). Sociocultural adaptation of international graduate students (Unpublished doctoral dissertation). Johnson \& Wales University. Providence, RI.

Yakushko, O., Davidson, M. M., \& Sanford-Martens, T. C. (2008). Seeking help in a foreign land: International students' use patterns for a U.S. university counseling center. Journal of College Counseling, 11(1), 6-18. http://dx.doi.org/10.1002/j.2161-1882.2008.tb00020.x

Yeh, C. J., \& Inose, M. (2003). International students' reported English fluency, social support satisfaction, and social connectedness as predictors of acculturative stress. Counseling Psychology Quarterly, 16(1), 15-28. http://dx.doi.org/10.1080/0951507031000114058

Zhang, X. (2011). Choices and challenges: Chinese graduate students' transitional issues at a Canadian university (Unpublished doctoral dissertation). University of Saskatchewan. Saskatoon, SK.

Zhou, Y. (2012). Listening to voices: Understanding Chinese students' journey at a Canadian university (Unpublished master thesis). University Of Saskatchewan Saskatoon, SK.

\section{Note}

This article is derived from the first author's unpublished dissertation research which was supervised by the second author, under the auspices of in the Department of Educational Administration, University of Saskatchewan in Canada.

\section{Copyrights}

Copyright for this article is retained by the author(s), with first publication rights granted to the journal.

This is an open-access article distributed under the terms and conditions of the Creative Commons Attribution license (http://creativecommons.org/licenses/by/3.0/). 